Situs Jurnal :http://ejournal.stiepancasetia.ac.id/index.php/jieb

Jilid 6 Nomor 3 November 2020

Hal $401-409$

\title{
PENGARUH GROSS PROFIT MARGIN, NET PROFIT MARGIN, RETURN ON EQUITY,RETURN ON ASSETS DAN EARNING PER SHARE TERHADAP HARGA SAHAM PADA PERUSAHAAN PROPERTY DAN REAL ESTATE YANG TERDAFTAR DI BURSA EFEK INDONESIA PERIODE 2015 - 2018
}

\section{Muhammad Fahmi}

Abstact :Empirically, this study aims to prove the effect of gross profit margin (GPM), net profit margin (NPM), return on equity (ROE), return on assets (ROA) and earnings per share (EPS) on stock prices in property and real companies. estate listed on the IDX for the period 2015 - 2018. The population in this study were property and real estate companies listed on the IDX for the period 2015 - 2018, namely 58 companies. The sampling technique was carried out by purposive sampling with a sample size of 29 companies. The analytical method used is multiple linear regression through SPSS version 20. The results prove that Gross Profit Margin, Net Profit Margin, Return On Equity, Return On Assets and Earning Per Share have a significant effect on stock prices in Property and Real Estate companies simultaneously. Meanwhile, partially, only Return On Equity has no effect on the stock price of property and real estate companies listed on the IDX for the 2015 - 2018 period.

Keywords : Gross Profit Margin, Net Profit Margin, Return On Equity, Return On Assets, Earnings Per Share and Stock Price

Abstrak : Secara empiris, penelitian ini ingin membuktikan pengaruh gross profit margin (GPM), net profit margin (NPM), return on equity (ROE), return on assets (ROA) dan earnings per share (EPS) terhadap harga saham pada perusahaan property dan real estate yang terdaftar di BEI periode 2015 - 2018. Populasi dalam penelitian ini adalah perusahaan property dan real estate yang terdaftar di BEI periode 2015 - 2018 yakni sebanyak 58 perusahaan. Teknik pengambilan sampel yang dilakukan secara purposive sampling dengan jumlah sampel sebanyak 29 perusahaan. Metode analisis yang digunakan adalah regresi linear berganda melalui SPSS versi 20. Hasil penelitian membuktikan bahwa Gross Profit Margin, Net Profit Margin, Return On Equity, Return On Assets dan Earning Per Share berpengaruh secara signifikan terhadap harga saham pada perusahaan Property dan Real Estate secara simultan. Sedangkan secara parsial, hanya Return On Equity yang tidak berpengaruh terhadap harga saham perusahaan property dan real estate yang terdaftar di BEI periode 2015 - 2018.

Kata Kunci : Gross Profit Margin, Net Profit Margin, Return On Equity, Return On Assets, Earnings Per Share Harga Saham 


\section{Latar Belakang.}

Perkembangan property dan real estate yang go public pertumbuhan yang baik. Hal ini ditandai dengan semakin banyaknya perusahaan property dan real estate yang masuk pasar modal. Maka, investor harus pintar memilih perusahaan yang mana yang terakhir ini terus meningkat, berdasarkan data yang di himpun oleh Asosiasi REI (Real Estate Indonesia) pertumbuhan bisnis property dan real estate yaitu meningkat sebesar 30 persen, tercatat menjadi 58 perusahaan property dan real estate yang terdaftar di Bursa Efek, bahkan REI memprediksikan pada tahun 2019 perusahaan property dan real estate akan terus mengalami peningkatan.

Meskipun terdapat prediksi yang menyatakan bahwa bisnis real estate masih memiliki peluang bagus, namun tetap saja sebuah bisnis memiliki resiko tersendiri khususnya dari sisi keuangan. Banyak cara yang bisa dilakukan dalam memprediksi keberlangsungan hidup perusahaan. Salah satunya dengan cara melihat perkembangan kinerja keuangan dari tahun ke tahun. Kinerja keuangan yang paling umum yang biasa nya dipakai adalah rasio profitabilitas.

Bagi para investor, nilai harga saham masih menjadi primadona bagi patokan bagi mereka untuk menentukan nilai investasi yang akan mereka ambil. Tujuan dari adanya seb uah investasi tentulah untuk mendapatkan keuntungan sebesar-besarnya. Hal inilah yang menjadi dasar kenapa penilaian kinerja keuangan melalui rasio profitabilitas menjadi acuan bagi para investor untuk menilai bagaimana tingkat pengembalian atas investasi yang akan atau sedang dilakukan di perusahaan tersebut.

Rasio profitabilitas juga digunakan oleh pihak perusahaan. Profitabilitas juga dapat digunakan untuk mengukur efisiensi penggunaan modal dalam suatu perusahaan dengan membandingkan antara laba dengan modal yang digunakan dalam operasi. Masalah profitabilitas ini penting bagi kelangsungan hidup dan perkembangan perusahaan. Bagi pimpinan perusahaan, profitabilitas dapat digunakan sebagai tolok ukur berhasil tidaknya perusahaan yang dipimpinnya.

Mengingat harga saham merupakan sesuatu yang fluktuatif dan cenderung tidak bisa diprediksi. Resiko investasi bagi para investor juga cukup tinggi. Tinggi rendahnya harga saham dipengaruhi faktor internal dan eksternal perusahaan. Faktor internal yang mempengaruhi, diantaranya kondisi atau kinerja perusahaan seperti berbagai pernyataan atau kebijakan internal perusahaan yang dikeluarkan oleh pihak manajemen perusahaan sedangkat faktor eksternal, diantaranya kebijakan pemerintah, kondisi politik, dan lain sebagainya.

Kemampuan rasio profitabilitas dalam rangka menggambarkan harapan laba yang akan didapatka oleh investor berdasarkan hasil pengukuran kinerja keuangan tahun lalu. Pengukuran rasio profitabilitas dapat dilakukan dengan menghitung gross profit margin (GPM), net profit margin (NPM), return on equity (ROE), return on assets (ROA) dan earnings per share (EPS). Oleh karena itu, penelitian ini ingin membuktikan bagaimana pengaruh gross profit margin (GPM), net profit margin (NPM), return on equity (ROE), return on assets (ROA) dan earnings per share (EPS) terhadap harga saham baik secara parsial maupun secara simultan pada perusahaan real estate and property yang terdaftar pada Bursa Efek Indonesia Periode tahun 20152018.

\section{Studi Literatur \\ Pasar Modal}

Pengertian Bursa Efek (pasar modal) Berdasarkan UU PM No. 8/1995 Bab III dan PP 45/95 Bab I dan Bab II, adalah perseroan terbatas (PT) yang telah mendapat izin usaha dari Bapepam untuk menyelenggarakan dan menyediakan sistem atau sarana untuk mempertemukan penawaran jual beli efek pihak lain dengan tujuan memperdagangkan efek

Darmadji dan Fakhruddin (2011:1) mendefinisikan Pasar modal sebagai pasar untuk berbagai instrument keuangan jangka panjang yang bisa diperjualbelikan, baik dalam bentuk hutang ataupun modal sendiri. Lainnya, Widoatmodjo

(2012:55) 
berpendapat jika pasar modal dapat dikatakan pasar abstrak, dimana yang diperjualbelikan adalah dana-dana jangka panjang, yaitu dana yang keterikatannya dalam investasi lebih dari satu tahun.

\section{Laporan Keuangan}

Menurut Kasmir (2013:7) dalam pengertian yang sederhana, laporan keuangan adalah laporan yang menunjukkan kondisi keuangan perusahaan pada saat ini atau dalam suatu periode tertentu. Maksud laporan keuangan yang menunjukkan kondisi keuangan perusahaan saat ini adalah merupakan kondisi terkini. Kondisi perusahaan terkini adalah keadaan keuangan perusahaan pada tanggal tertentu (untuk neraca) dan periode tertentu (untuk laporan laba rugi). Laporan keuangan menggambarkan pospos keuangan perusahaan yang diperoleh dalam suatu periode.

Menurut Ikatan Akuntan Indonesia Indonesia (2009:1), laporan keuangan meliputi bagian dari proses laporan keuangan. Menurut Munawir (2010:5), pada umumnya laporan keuangan itu terdiri dari neraca dan perhitungan laba-rugi serta laporan perubahan ekuitas. Neraca menunjukkan/ menggambarkan jumlah aset, kewajiban dan ekuitas dari suatu perusahaan pada tanggal tertentu. Sedangkan perhitungan (laporan) laba-rugi memperlihatkan hasil yang telah dicapai oleh perusahaan serta beban yang terjadi selama periode tertentu, dan laporan perubahan ekuitas menunjukkan sumber dan penggunaan atau alasan-alasan yang menyebabkan perubahan ekuitas perusahaan.

\section{Rasio Profitabilitas}

Profitabilitas merupakan salah satu rasio keuangan yang menunjukkan perbandingan antara laba dengan aktiva atau modal yang menghasilkan laba tersebut. Jadi dengan kata lain, profitablitas adalah kemampuan perusahaan menghasilkan laba selama periode tertentu. Cara penilaian profitabilitas suatu perusahaan bermacam-macam dan tergantung pada laba dan aktiva atau modal mana yang akan diperbandingkan atau dengan lainnya. Bisa laba yang berasal dari operasi suatu usaha, laba bersih setelah pajak dengan aktiva operasi, laba bersih setelah pajak dengan seluruh aktiva, atau laba setelah pajak diperbandingkan dengan modal sendiri.
Menurut Munawir (2010) Gross Profit Margin adalah rasio atau perimbangan antara gross profit (laba kotor) yang diperoleh perusahaan dengan tingkat penjualan yang dicapai pada periode yang sama.

Brigham dan Houston (2010:146) "Net Profit Margin (NPM) adalah "Rasio yang mengukur laba bersih per dolar penjualan yang dihitung dengan membagi laba bersih dengan penjualan." NPM yang tinggi menandakan kemampuan perusahaan menghasilkan laba yang tinggi pada tingkat penjualan tertentu.

Brigham dan Houston (2010:149), Return on Equity (ROE) merupakan rasio bersih terhadap ekuitas biasa mengukur tingkat pengembalian atas investasi pemegang saham biasa. Return On Equity (ROE) digunakan untuk mengukur kemampuan perusahaan memperoleh laba yang tersedia bagi pemegang saham perusahaan. Rasio itu merupakan ukuran profitabilitas dari sudut pandang pemegang saham. Meskipun rasio ini mengukur laba dari sudut pandang pemegang saham, rasio ini tidak memperhitungkan dividen maupun capital gain untuk pemegang saham.

Return On Assets (ROA) yang positif menunjukkan bahwa total aset yang digunakan untuk operasi perusahaan mampu memberikan laba bagi perusahaan, sebaliknya ROA negatif menunjukkan bahwa dari total aset yang digunakan, perusahaan mendapatkan kerugian. Hal ini menujukkan kemampuan dari modal yang diinvestasikan secara keseluruhan belum mampu untuk menghasilkan laba. Kasmir (2012:202) menyatakan bahwa "ROA merupakan rasio yang menunjukkan hasil (return) atas jumlah aset yang digunakan dalam perusahaan atau suatu ukuran tentang aktivitas manajemen."

Earning Per Share (EPS) menurut Brigham dan Houston (2010:33) adalah pendapatan bersih yang tersedia dibagi jumlah lembar saham yang beredar." Laba merupakan alat ukur utama kesuksesan suatu perusahaan, karena itu para pemodal seringkali memusatkan perhatian pada besarnya Earning Per Share (EPS) dalam melakukan analisis saham. Harga saham merupakan salah satu indikator pengelolaan perusahaan. Keberhasilan dalam 
menghasilkan keuntungan akan memberikan kepuasan bagi investor yang rasional. Harga saham yang cukup tinggi akan memberikan keuntungan, yaitu berupa capital gain dan citra yang lebih baik bagi perusahaan sehingga memudahkan bagi manajemen untuk mendapatkan dana dari luar perusahaan. Jogiyanto (2008:167) "Harga saham adalah harga suatu saham yang terjadi di pasar bursa pada saat tertentu yang ditentukan oleh pelaku pasar dan ditentukan oleh permintaan dan penawaran saham yang bersangkutan di pasar modal.

\section{Metode Penelitian}

Penelitian ini merupakan penelitian kolerasi, yang bertujuan untuk melihat apakah ada hubungan yang terjadi antara satu variabel dengan variabel yang lain dan seberapa kuat hubungan tersebut. Variabel yang dimaksud meliputi variabel yang dipengaruhi (dependent variable) yaitu gross profit margin (GPM), net profit margin (NPM), return on equity (ROE), return on assets (ROA) dan earnings per share (EPS) dan variabel yang mempengaruhi (independent variable) yaitu Harga Saham.

Hubungan rasio profitabilitas yang dianggap mampu mempengaruhi harga saham secara positif karena Profitabilitas dianggap mampu mengukur sejauh mana kemampuan suatu perusahaan dalam memperoleh laba. Dan laba merupakan faktor utama mengukur tingkat efektifitas dan efisiensi perusahaan dengan seluruh dana dan sumber daya perusahaan (wulandari \& badjra, 2019). Sehingga penelitian ini memiliki kerangka pikir yang digambarkan sebagai berikut:

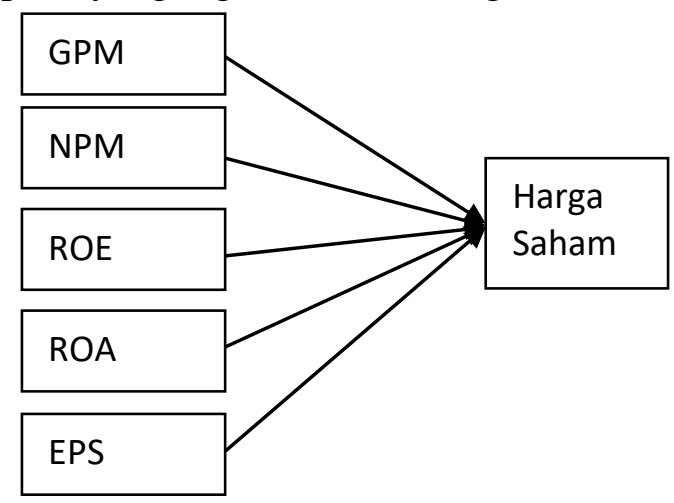

Gambar 1 : Kerangka Pikir
Berdasarkan kerangka pikir tersebut, diketahui hipotesis yang dikembangkan antara lain:

$\mathrm{H}_{1}=$ gross profit margin (GPM) berpengaruh positif terhadap Harga Saham

$\mathrm{H}_{2}=$ net profit margin (NPM) berpengaruh positif terhadap Harga Saham

$\mathrm{H}_{3}=$ return on equity (ROE) berpengaruh positif terhadap Harga Saham

$\mathrm{H}_{4}=$ return on assets (ROA) berpengaruh positif terhadap Harga Saham

$\mathrm{H}_{5}=$ earnings per share (EPS) berpengaruh positif terhadap Harga Saham

$\mathrm{H}_{5}=$ gross profit margin (GPM) berpengaruh positif terhadap Harga Saham

$\mathrm{H}_{6}=$ gross profit margin (GPM), net profit margin (NPM), return on equity (ROE), return on assets (ROA) dan earnings per share (EPS) bersamasama berpengaruh terhadap Harga Saham

Penelitian ini mengambil objek perusahaan property dan real estate yang terdaftar di BEI dengan populasi sebanyak 58 perusahaan. Pengambilan sampel menggunakan metode purpose sampling, dengan kriteria yaitu perusahaan property dan real estate yang terdaftar di BEI tahun 2015 sampai dengan tahun 2018 serta perusahaan property dan real estate memiliki laporan keuangan lengkap dan telah menerbitkan laporan keuangan ke BEI setiap tahunnya sehingga diperoleh 29 sampel perusahaan yang memenuhi kriteria. Pembuktian penelitian ini dilakukan dengan cara : (a) mengumpulkan dan mentabulasi data yang diambil dari laporan keuangan perusahaan (b) melakukan uji asumsi klasik yang terdiri dari uji normalitas, uji multikolonearitas, uji autokorelasi, uji heteroskedatisitas, (c) pengujian hipotesis dengan uji $\mathrm{F}$ (simultan) dan uji $\mathrm{t}$ (parsial) dan koefisien determinasi (R). Metode pengolahan data menggunakan program SPSS untuk menjawab hipotesis.

Hasil penelitian ini diharapkan dapat memberikan kontribusi untuk pengembangan teori ilmu akuntansi keuangan, untuk menambah wawasan dan pengetahuan terutama yang berkaitan dengan laporan keuangan. Sedangkan untuk para peneliti 
selanjutnya diharapkan dapat menjadi pembanding dan mampu menjadi acuan untuk penelitian selanjutnya yang lebih baik. Selain itu bisa menjadi salah satu bahan pertimbangan bagi investor dalam memutuskan berinvestasi di sektor ini.

\section{Definisi Operasional Variabel.}

Variabel Independen (X) dalam penelitian ini adalah :
a. Gross Profit Margin (X.1), merupakan persentase laba kotor dibandingkan dengan penjualan.
b. Net Profit Margin (X.2), merupakan rasio yang digunakan mengukur laba bersih setelah pajak dibandingkan dengan penjualan.

c. Return On Equity (X.3), atau hasil pengembalian ekuitas atau rentabilitas modal sendiri merupakan rasio untuk mengukur laba bersih sesudah pajak dengan modal sendiri.

d. Return On Assets (X.4), atau hasil pengembalian aset dalam efektivitas merupakan rasio untuk mengukur laba bersih sesudah pajak dengan total asset perusahaan.

e. Earning Per Share (X.5), merupakan rasio yang menunjukkan berapa besar keuntungan yang diperoleh investor atau pemegang saham per lembar saham.

Variabel Dependen (Y) penelitian ini adalah harga saham. Harga saham yang digunakan peneliti yaitu harga saham pada harga penutupan (Closing price) tiap akhir tahun 2015 - 2018 karena merupakan harga saham yang tertera dilaporan keuangan perusahaan pada tiap akhir tahun.

\section{Teknik Analisis Data.}

\section{Uji Asumsi Klasik}

Uji Asumsi klasik dilakukan untuk menghindari kemungkinan terjadinya penyimpangan dalam analisis, maka perlu adanya pengujian terhadap beberapa asumsi klasik.

Uji Normalitas

Uji normalitas bertujuan untuk menguji apakah dalam model regresi, variabel independen dan variabel dependen keduanya memiliki distribusi normal atau tidak.

Uji Autokoreksi
Uji auto korelasi bertujuan untuk, menguji apakah dalam suatu model regresi ada korelasi kesalahan penganggu (karena residual) pada periode $\mathrm{t}$ dengan periode $\mathrm{t}-1$.

Uji Multikolinearitas

Uji multikolinearitas digunakan untuk mengetahui ada atau tidaknya penyimpangan asumsi klasik multikolonearitas yaitu adanya hubungan linear antar variabel independen dalam model regresi. Pengujian terhadap variabel tersebut dilakukan dengan melihat nilai Tolerance dan Variance Inflation Fcktor, jika terdapat nilai Tolerance diatas 0,1 dan nilai VIF dibawah 10 , maka tidak terdapat masalah multikolenearitas.

Uji Heterokedastisitas

Pengujian heterokedastisitas dapat dilakukan dengan melihat sebaran grafik plot antara prediksi variabel terikat (dependen) yaitu ZPRED sebagai (X) dan nilai residualnya SRESID sebagai (Y).

\section{Analisis Regresi Berganda}

Metode analisis data yang digunakan adalah regresi linier berganda (multi linier regression method), yaitu menguji pengaruh dua atau lebih variabel independen terhadap satu variabel dependen. Model persamaan regresinya sebagai berikut:

$\mathrm{Y}=\mathrm{a}+\mathrm{bX} 1+\mathrm{bX} 2+\mathrm{bX} 3+\mathrm{bX} 4+\mathrm{bX} 5+\mathrm{e}$

$\mathrm{Y}=$ Harga Saham

$\mathrm{a}=$ Konstanta

$\mathrm{b}=$ Beta

$\mathrm{x} 1=$ gross profit margin $(\mathrm{GPM})$,

$\mathrm{x} 2=$ net profit margin $(\mathrm{NPM})$,

$\mathrm{x} 3=$ return on equity $(\mathrm{ROE})$,

$\mathrm{x} 4=$ return on assets $(\mathrm{ROA})$

$\mathrm{x} 5=$ earnings per share $(\mathrm{EPS})$

$\mathrm{e}=$ error

\section{Pengujian Hipotesis}

Langkah-langkah untuk menguji hipotesis-hipotesis yang diajukan didalam penelitian ini adalah sebagai berikut ;

Uji F

Pengujian secara simultan menggunakan uji $F$ (pengujian signifikansi secara simultan).

Uji t

Pengujian secara parsial menggunakan uji t (pengujian signifikan secara parsial).

Koefisiensi Determinasi $\left(\mathrm{R}^{2}\right)$

JIEB, Jilid 6, No 3, November 2020 
Pengujian ini dilakukan untuk mengetahui sejauh mana model penelitian akan menjelaskan hubungan antara variabel independen dengan variabel dependen

\section{HASIL PENELITIAN \\ Gambaran Umum Objek Penelitian}

Industri property dan real estate adalah salah satu industri yang ikut berperan serta dalam pasar modal, disamping industri lainnya seperti inustri manufaktur, perbankan, pertambangan, pertanian dan lain-lain. Property dan real estate merupakan perusahaan yang memiliki hak kepemilikan atas tanah dan bangunan yang didirikan diatasnya. Perusahaan property dan real estate adalah perusahaan yang menyediakan berbagai keperluan berupa apartemen, rumah, tanah kavlingan ruko dan property lainnya. Dan berikut ini adalah perusahaan property dan real estate yang terdaftar di BEI yang menjadi sampel dalam penelitian :

\section{Agung Podomoro Land Tbk (APLN)}

2. Alam Sutera Realty Tbk (ASRI)

3. Bekasi Asri Pemula Tbk (BAPA)

4. Bekasi Fajar Industrial Estate Tbk (BEST)

5. Sentul City Tbk (BKSL)

6. Bumi Serpong Damai Tbk (BSDE)

7. Ciputra Development Tbk (CTRA)

8. Duta Anggada Realty Tbk (DART)

9. Intiland Development Tbk (DILD)

10. Duta Pertiwi Tbk (DUTI)

11. PT Megapolitan Developments Tbk

12. Gading Development Tbk (GAMA)

13. Gowa Makassar Tourism Development Tbk (GMTD)

14. Perdana Gapuraprima Tbk (GPRA)

15. Greenwood Sejahtera Tbk (GWSA)

16. Jaya Real Property Tbk (JRPT)

17. Lippo Cikarang Tbk (LPCK)

18. Lippo Karawaci Tbk (LPKR

19. Modernland Realty Tbk (MDLN)

20. Metropolitan Kentjana Tbk (MKPI)

21. Plaza Indonesia Realty Tbk (PLIN)

22. Pudjiadi Prestige Tbk (PUDP)

23. Pakuwon Jati Tbk (PWON)

24. Roda Vivatex Tbk (RDTX)
25. Pikko Land Development Tbk (RODA)

26. Danayasa Arthatama Tbk (SCBD)

27. Suryamas Dutamakmur Tbk (SMDM)

28. Summarecon Agung Tbk (SMRA)

29. Metropolitan Land Tbk (MTLA)

\section{Hasil Penelitian}

Berdasarkan pengujian asumsi klasik diketahui bahwa:

Uji Asumsi Klasik

\section{Uji Normalitas Data}

Berdasarkan dari hasil penelitian uji normalitas data menunjukkan bahwa nilai $0,075(7.5 \%)$ atau berada diatas $5 \%$ yang berarti bahwa nilai residual dinyatakan menyebar secara normal.

Uji Autokorelasi

Berdasarkan dari hasil, menunjukkan nilai Durbin Watson diketahui adalah 0.991. Sedangkan tabel Durbin Watson nilai du adalah 1.7878 sehingga dari hasil perhitungan uji autokorelasi dengan kriteria perhitungan Durbin Watson sebagai berikut $\mathrm{du}<\mathrm{dw}<4-\mathrm{du}$ yaitu $1.7878<0.991<2.2122$ yang artinya model regresi ini terdapat masalah autokorelasi.

Uji Multikolinearitas

Tabel 1 Hasil Uji Multikolinearitas

\begin{tabular}{|c|c|c|}
\hline Variabel & Tolerance & VIF \\
\hline GPM & 0,720 & 1,389 \\
\hline NPM & 0,367 & 2,722 \\
\hline ROE & 0,425 & 2,354 \\
\hline ROA & 0,394 & 2,536 \\
\hline EPS & 0,439 & 2,277 \\
\hline
\end{tabular}

Sumber : Hasil Olah Data SPSS

Berdasarkan tabel 1 di atas diketahui bahwa semua variabel memiliki nilai tolerance di bawah 1 dan nilai VIF diatas 1 , sehingga dapat dikatakan bahwa tidak terjadi multikolinearitas.

Uji Heterokedastisitas

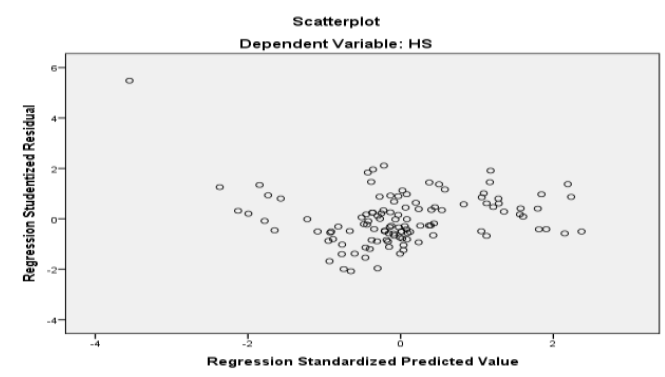

Gambar 2 : Sebaran grafik plot 
Pengujian heterokedastisitas dapat dilakukan dengan melihat sebaran grafik plot antara prediksi variabel terikat (dependen) yaitu ZPRED sebagai (X) dan nilai residualnya SRESID sebagai (Y). Berdasarkan gambar 2 yaitu grafik scatterplot di atas menunjukkan bahwa nilai prediksi variabel terikat (dependen) yaitu ZPRED sebagai (X) dengan residual SRESID sebagai (Y) diketahui tidak membentuk pola, serta titik-titik menyebar diatas dan dibawah angka 0 pada sumbu $Y$, atau tidak terjadi masalah heterokedastisitas.

\section{Analisis Regresi Berganda}

Berdasarkan pengujian melalui SPSS diketahui data yang dirangkum dalam tabel 2 berikut ini:

Tabel 2 : Hasil Pengujian SPSS

\begin{tabular}{|c|c|c|c|}
\hline Variabel X & Beta & Signifikan & Keterangan \\
\hline Konstanta & 1,975 & 0,000 & \\
\hline GPM & 0,009 & 0,015 & Berpengaruh \\
\hline NPM & $-0,730$ & 0,000 & Berpengaruh \\
\hline ROE & $-0,139$ & 0,128 & $\begin{array}{c}\text { Tidak } \\
\text { Berpengaruh }\end{array}$ \\
\hline ROA & 0,049 & 0,000 & Berpengaruh \\
\hline EPS & 0,700 & 0,000 & Berpengaruh \\
\hline R & 0,852 & R Square & 0,727 \\
\hline $\begin{array}{c}\text { Adjust R } \\
\text { Square }\end{array}$ & 0,717 & Annova & 0,000 \\
\hline
\end{tabular}

Variabel Y = Harga Saham

Sumber : Hasil Olah Data SPSS

Dari tabel 2 di atas, Persamaan regresi linier berganda yang berbentuk adalah

\section{$\mathrm{Y}=1,975+0,009 \mathrm{X} 1-0,730 \mathrm{X} 2-0,139 \mathrm{X} 3+$ $0,049 \times 4+0,700 \times 5$}

Berdasarkan persamaan di atas diketahui bahwa tanpa dipengaruhi rasio prifitabilias, maka harga saham akan mengalami kenaikan sebesar 1,975. Koefisiesi regresi GPM sebesar 0,009 menunjukan bahwa kenaikan GPM sebesar 1 persen, akan menaikan harga saham sebesar 0,009. Koefisiensi NPM yang menunjukan hasil negatif sebesar - 0,703 menunjukan hubungan yang tidak searah dengan harga saham. Maksudnya apabila NPM naik sebesar 1 persen, maka harga saham justru akan turun sebesar 0,703. Demikian pula koefisiensi dari ROE yang juga menunjukan angka $-0,139$ yang berarti saat nilai $\mathrm{ROE}$ naik 1 persen, maka harga saham justru akan turun sebesar 0,139.

Koefisiensi ROA bernilai positif 0,139 yang artinya ditemukan hubungan searah antara ROA dengan harga saham. Yang artinya saat ROA naik sebesar $1 \%$, maka harga saham akn mengalami kenaikan sebesar 0,193. Demikian pula hubungan antara EPS yang turut menemukan hubungan positif sebesar 0,700. Sehingga dapat diartikan bahwa dengan adanya kenaikan pada EPS sebesar $1 \%$, akan turut naikkan harga saham sebesar 0,700

\section{Hasil Uji Hipotesis}

\section{Hubungan GPM dan Harga Saham}

GPM merupakan persentase dari laba kotor dibandingkan dengan penjualan (sales). Dalam pengujian secara partial diketahui bahwa nilai koefisiensi yang diperoleh adalah positif. Serta nilai signifikannya berada di bawah level of significant yaitu sebesar 0,015 . Sehingga dapat dikatakan bahwa rasio ini mampu menunjukan pengaruh positif dengan harga saham. Pelitian ini mendukung penelitian Alfianti (2017).

\section{Hubungan NPM dengan Harga Saham}

NPM merupakan rasio yang menunjukkan kemampuan perusahaan menghasilkan keuntungan bersih setelah pajak. Dan dalam penelitian ini menemukan koefisien yang negative namun nilai signifikannya di bawah level of significant yaitu 0,000 . Hal ini mengindikasikan bahwa NPM mampu mempengaruhi harga saham, namun hubungan yang erat tersebut merupakan hubungan yang tidak searah. Penelitian ini sama seperti penelitian Murniati (2016) dimana NPM berpengaruh negative dan signifikan terhadap harga saham, dan tidak sependapat dengan Wulandari dan Badjra (2019) dan Kundiman \& Hakim (2016),

\section{Hubungan ROE dengan Harga Saham}

ROE merupakan rasio yang digunakan untuk mengukur laba bersih untuk pemegang saham yang dimana dibagi dengan total ekuitas para pemegang saham. Hasil penelitian ini menunjukan nilai koefisiensi negative dengan perolehan nilai signifikansi lebih dari level of significant yaitu 0,128 . 
Artinya ROE tidak menunjukan pengaruh signifikan terhadap harga saham serta memiliki sifat terbalik atau negative terhadap harga saham tersebut. hasil ini konsten dengan

\section{Hubungan ROA dengan Harga Saham}

ROA merupakan rasio yang digunakan untuk mengukur kemampuan perusahaan dalam memperoleh laba yang dimilikinya. Dalam penelitian ini diketahui bahwa nilai signifikan yang diperolehnya adalah 0,00 atau di bawah nilai level signifikansi yang berarti ROA mampu mempengaruhi harga saham secara signifikan dan positif, atau hipotesis ke 4 dapat diterima. Ini konsisten dengan penelitian Kundiman \& Hakim (2016), Murniati (2016), serta Wulandari dan Badjra (2019)

\section{Hubungan EPS dengan Harga Saham}

EPS merupakan Rasio yang menujukkan berapa besar kemampuan per lembar saham dalam menghasilkan laba. Dalam penelitian ini ditemukan nilai koefisiensi yang positif dan nilai sgnifikan di bawah level of significant yaitu sebesar 0,000 yang berarti bahwa rasio ini secara positif mampu mempengaruhi harga saham. Penelitian ini mendukung penelitian Jaenuddin (2012) dan tidak mendukung penelitian tyas dan saputra (2016).

Hubungan GPM, NPM, ROE, ROA dan EPS secara simultan terhadap Harga Saham.

Dalam pengujian secara simultan, diketahui bahwa rasio profitabilitas yang dalam penelitian ini melalui Gross Profit Margin, Net Profit Margin, Return On Equity, Return On Assets dan Earning Per Share diuji dengan uji f terhadap harga saham. Dan hasilnya menunjukan nilai signifikannya menunjukan hasi di bawah level of significant yaitu 0,000 . Sehingga dapat disimpulkan bahwa GPm, NPM, ROE, ROA dan EPS dapat mempengaruhi harga saham.

\section{Uji Koefisiensi Determinasi}

Berdasarkan Besarnya nilai koefisien determinasi sebesar $71.4 \%$ menunjukkan adanya hubungan yang tinggi antara Gross Profit Margin, Net Profit Margin, Return On Equity, Return On Assets dan Earning Per Share yang menjadi variabel independen dengan harga saham sebagai variabel dependen.

\section{KESIMPULAN DAN SARAN Kesimpulan}

Investor di pasar modal akan memperhatikan kemampuan perusahaan untuk menghasilkan dan meningkatkan laba (profit). Semakin baik kemampuan tersebut maka semakin besar kemungkinan return yang akan diperoleh sekaligus akan berpengaruh pada harga saham. Untuk mengukur kemampuan ini maka pengukuran melalui rasio profitabilitas diperlukan salah satunya dengan menggunakan rasio Gross Profit Margin, Net Profit Margin, Return On Equity, Return On Assets dan Earning Per Share.

Harga saham yang merupakan salah satu cermin dari nilai perusahaan merupakan nilai yang memiliki nilai yang fluktuatif. Dan investor dapat melakukan analisis fundamental untuk memprediksi harga saham tersebut. dalam penelitian ini Gross Profit Margin, Net Profit Margin, Return On Equity, Return On Assets dan Earning Per Share secara bersama - sama ternyata mampu mempengaruhi secara positif terhadap harga saham.

Namun, pengujian secara partial menemukan hanya ROE yang tidak berpengaruh dan memiliki hubungan negative dengan harga saham. Sedangkan NPM walaupun mampu mempengaruhi harga saham, namun hubungannya negative artinya jika NPM naik maka harga saham turun, dan sebaliknya. Sedangkan GPM, ROA, dan EPS mampu menunjukan hasil positif dan berpengaruh secara signifikan terhadap harga saham.

\section{Saran}

Penelitian ini hanya mengambil kinerja keuangan yang berasal dari rasio profitabilitas saja. Padahal ada beberapa rasio keuanganlagi yang bisa diteliti oleh peneliti selanjutnya. Mengingat harga saham merupakan salah bagian penting dari pertimbangan investor memilih investasi di perusahaan yang memiliki kemampuan atau kinerja keuangan yang baik.

JIEB, Jilid 6, No 3, November 2020 


\section{DAFTAR PUSTAKA}

Alfianti A, Dinda. Andarini, Sonja. 2017. Pengaruh profitabilitas terhadap harga saham pada perusahaan makanan dan minuman yang terdaftar di bursa efek indonesia. Jurnal Bisnis Indonesia. Vol 8 , No 1

Brigham, Eugene F. Dan J.F. Houston. 2010. Dasar-Dasar Manajemen Keuangan. Edisi 11. Jakarta: Salemba Empat

Darmadji, T. dan H. M. Fakhruddin. 2011. Pasar Modal Indonesia. Edisi Ketiga. Jakarta: Salemba Empat.

Hermanto, Bambang dan Mulyo Agung. 2012. Analisa Laporan Keuangan. Cetakan pertama. Jakarta : Lentera Ilmu Cendekia

Jogiyanto. (2008). Analisis dan Desain Sistem Informasi : Pendekatan Terstruktur. Teori dan Praktek Aplikasi Bisnis. Yogyakarta: Andi.

Jusup, Al - Haryono. 2014. Dasar-dasar Akuntansi jilid 2. Edisi Ketujuh. Yogyakarta : Universitas Gajah Mada.

Kasmir. 2013. Bank dan Lembaga Keuangan Lainnya. Jakarta. Rajawali Pers

Kundiman, A., \& Hakim, L. (2016). Pengaruh Current Ratio, Debt To Equity Ratio, Return On Asset, Return On Equity Terhadap Harga Saham Pada Indeks LQ 45 Di BEI Periode 20102014. Among Makarti, 9(18), 80-98.

Munawir, S. 2010. Analisis laporan Keuangan Edisi keempat. Cetakan Kelima. Belas. Yogyakarta: Liberty.

Murniati, S. 2016. Effect Of Capital Structure, Company Size And Profitability on the Stock Price of Food And Beverage Companies Listed on the Indonesia Stock Exchange. Information Management And Business Review, 8(1), 23-29. Retrieved from:https://ifrnd.org/journal/index.php/i mbr/article/view/1192. Retrieved from http://jurnal.stieama.ac.id/index.php/ama /article/viewFile/140/131
Tyas, Rizqi Aning dan Saputra, Rishi Septa. 2016. Analisis Pengaruh Profitabilitas Terhadap Harga Saham (Studi Kasus Perusahaan telekomunikasi Yang Terdaftar di Bursa Efek Indonesia (BEI) Periode 2012-2014). Jurnal Online Insan Akuntan vol 1 No 1. Juni Halaman 7791

Widoatmodjo, Sawidji. 2012. Cara Sehat Investasi di Pasar Modal. Edisi Revisi. Jakarta: PT. Jurnalindo Aksara Grafika

Wulandari, Ade Indah dan Badjra, Ida Bagus. 2019. Pengaruh Profitabilitas Terhadap Harga Saham Pada perusahaan LQ-45 Di Bursa efek Indomesia (BEI). E-Jurnal Manajemen Vol 8 No. 9, 2019. UNUD 